\title{
COMMUNITY PARTICIPATION, RISK MANAGEMENT AND ECOTOURISM SUSTAINABILITY ISSUES IN GHANA
}

\author{
Gabriel ESHUN* \\ Tourism Programme, KNUST, P.M.B. Kumasi, A/R. Ghana; University of Johannesburg, \\ School of Tourism and Hospitality, South Africa; e-mail: gabriel_eshun_knust@yahoo.co.uk. \\ Tembi M. TICHAAWA \\ University of Johannesburg, School of Tourism and Hospitality, \\ College of Business and Economics, South Africa, e-mail: tembit@uj.ac.za

\begin{abstract}
Citation: Eshun, G. \& Tichaawa, T.M. (2020). COMMUNITY PARTICIPATION, RISK MANAGEMENT AND ECOTOURISM SUSTAINABILITY ISSUES IN GHANA. GeoJournal of Tourism and Geosites, 28(1), 313-331. https://doi.org/10.30892/gtg.28125-472
\end{abstract}

\begin{abstract}
This study analysed the nexus of risk management and local community participation within the context of ecotourism sustainability. A mixed-methodological approach was employed in data collection and analysis. A sample of 210 people were conveniently selected from the two study communities. The study results were categorised under the following themes; NGOs and their roles in ensuring ecotourism sustainability; community participation toward ecotourism sustainability; government's role in ecotourism marketing and mechanisms; local communities' understanding of ecotourism sustainability, and tourist relationship with local communities. Overall, the study revealed land encroachment, illegal logging, extreme weather, poaching, bushfires and robbery as the main risks threatening the sustainability of the ecotourism sites in Ghana. In sum, the empirical and theoretical outcomes of the study can help toward developing practical risk management strategies for sustainable ecotourism development in Ghana.
\end{abstract}

Key words: Locals, Risk management, Sustainability, Ecotourism Development, Ghana

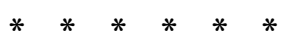

\section{INTRODUCTION}

The concept of sustainability in ecotourism literature continues to receive research attention especially in the developing countries, owing to it being seen as a win-win strategy for purposes of biodiversity conservation and economic development (AmoakoAcheampong, 2013; Yang \& Nair, 2014; Romero-Brito et al., 2016; Ramón-Hidalgo et al., 2018). Although ecotourism cannot replace mass tourism, it is moving away from simply being considered a niche-market to becoming a flagship tourism market in such countries as Ecuador, Nepal, Costa Rica, Kenya and South Africa (Honey, 2008; Akama et al., 2011; Fennell, 2014). However, a number of ecotourism sites are either rapidly degrading, or

\footnotetext{
* Corresponding author
} 
have already been degraded (Honey, 2008; Fennell, 2014; Romero-Brito et al., 2016). Current works on the degradation of ecotourism sites have cited issues of poaching, human-animal conflicts, local community marginalisation, greenwashing, marginalisation of local ecological knowledge, leaking and diversion of funds for biodiversity conservation as the overarching causes (Adjewodah \& Beier, 2004; Yang Romero-Brito et al., 2016; Ramón-Hidalgo et al., 2018; Eshun \& Tichaawa, 2019). Indeed, literature on ecotourism positions community participation congruently with the goal of achieving sustainability through the niche-market (Tosun, 2000; Scheyvens \& Momsen, 2008; Akama et al., 2011; Becken et al., 2014; Eshun \& Tonto, 2014; Harilal \& Tichaawa, $2018 \mathrm{~b})$. The above has called for critical research into the nexus of community participation in ecotourism, risk management and ecotourism sustainability (Kanlayanasukho, 2014; Yang \& Nair, 2014; Rogerson, 2015; Harilal et al., 2019).

Despite the increasing research on the potential of ecotourism in sub-Saharan African countries (Akama et al., 2011; Agyeman, 2013; Amoako-Acheampong, 2013; Mensah \& Adofo, 2013; Eshun \& Tagoe-Darko, 2015; Dumbe et al., 2018; Harilal \& Tichaawa, 2018a; Eshun \& Tichaawa, 2019), little published evidence from sub-Saharan Africa exists, that teases out the nexus of sustainability, local community participation and risk management at ecotourism sites. Literature on tourism is replete with the premise that health, safety and security issues greatly influence a destination's appeal to actual and potential visitors (Bentley et al., 2004; Moreira, 2007; Gabbatt, 2010; Tarlow, 2011; Idowu et al., 2014; Yang \& Nair, 2014; Hajibaba et al., 2016). Indeed, empirical work into the nexus of risk management and ecotourism is germane from the standpoint that ecotourism as nature-based tourism involves coming often in direct contact with especially faunal species, which can pose a direct danger to visitors (Honey, 2008; Amoako-Acheampong, 2013; Yang \& Nair, 2014). The panoply of activities that can be associated with ecotourism sites such as traipsing through rainforests, climbing mountains, scuba diving, canopy walking, sleeping in treehouses, camping in the woods, canoeing, paragliding, direct contact with local communities among others place risk management issues directly within the milieu of ecotourism sustainability (Tosun, 2000; Tarlow, 2011; Pennington-Gray \& Schroeder, 2013; Becken et al., 2014; Ural, 2015).

Since the 1990s, Ghana has been receiving visitors who could be classed as ecotourists. Currently, Ghana is ranked among the top 25\% of African countries with the greatest diversity of wildlife, inter alia: mammals (220 species), birds (725 species), and butterflies (850 species). Ghana is also home to many endangered International Union for Conservation of Nature (IUCN) - Red Data Book Species, including plants (34 species), birds (10 species), mammals (17 species), and reptiles (5 species) (Eshun, 2014). In 2018, the tourism industry in Ghana maintained its position as the fourth highest foreign exchange earner for the country after cocoa, gold and oil and gas. This notwithstanding, risk management practices at ecotourism sites are largely absent in literature despite the impressive literature on ecotourism in the country (see Hens, 2006; AmoakoAcheampong, 2013; Mensah \& Adofo, 2013; Eshun \& Tonto, 2014; Dumbe et al., 2018; Eshun \& Tichaawa, 2019). According to the National Disaster Management Organisation ([NADMO], 2015), tourism sites in Ghana, for the past five years, have recorded the occurrence of avoidable accidents. An example of such an accident is the one that occurred at the Bunso Arboretum, where the canopy walkway collapsed, due to poor managerial attitudes that neglected the walkway's precise physical carrying capacity. The above signifies that good sustainable practices are not ensured at some of the ecotourism sites, thus militating against ecotourism goals serving as a viable tool for the attainment of biodiversity conservation and local development. The current paper, therefore, seeks to contribute to the filling of this knowledge gap in ecotourism research. 


\section{LITERATURE REVIEW}

Ecotourism, in depicting the interaction between the tourists and the local resources, focuses on capitalist and community development, poverty alleviation and the conservation of wildlife and plants (Regmi and Walter, 2017). The unique selling proposition of ecotourism is its much-publicised image of generating local benefits and also the way in which it affects how tourists perceive, experience and learn about nature, as well as about its landscape, biodiversity, habitats and cultural relics (Kiper, 2013; Eshun and Tagoe-Darko, 2015). Rusko and Prochazkova (2011) note that sustainable development is concerned with development that does not erode ecological, cultural, social, economic and political systems. Recent studies have outlined that sustainability has grown beyond the environment to include human assets and institutions.

In addition, Ural (2015) argues that the sustainability of a tourism destination is significantly influenced by its ability to adapt to changing market conditions, to use resources efficiently and to deliver innovative planning and development strategies regarding risk management. One key consideration that falls under sustainable ecotourism is the consideration of minimising risks, especially at ecotourism sites, so as to ensure safety, health and cutting-edge experiences for the visitors (Eshun, 2011; Amoako-Acheampong, 2013). The 'moments of truth' for ecotourism business lie in its adherence to sustainable tourism principles (Fennell, 2014). Such moments may be seen in the quality of the drinking water, the degree of security provided for tourists, the good culinary services, and environmental education (Angelkova et al., 2012). Ultimately, the rubrics of risk, crisis and disaster management reflect the congruence of tourism risk management (Moreira, 2007). Although the rubrics are used interchangeably, they are not without their fine distinctions. Though the term 'risk management' can be nebulous in meaning, such management in tourism refers to the planning and implementation of processes that are directed towards managing the adverse effects of crises and disasters on tourism (Tarlow, 2011). As the marketplace is moving at a nanosecond pace, tourism risk management has become an ongoing process, entailing the regular monitoring and review of hazards and the elements at risk, as well as the progress, outcomes and efficacy of risk treatment measures (PATA [Pacific Area Travel Association], 2011).

Generally, a crisis affecting the tourism sector manifests as an event that damages the market potential and the reputation of a tourism business and the neighbouring regions (PATA, 2003; PATA, 2011; Yang \& Nair, 2014; World Travel and Tourism Council, 2019). For example, due to the outbreak of Ebola in 2014 in West Africa, of which the Gambia did not report even a single case, the tourists' hotel reservations dropped by 65\% (Idowu et al., 2014). Some authors distinguish between a 'crisis' and a 'disaster', with the key differences being that crises tend to be more predictable, are caused by anthropogenic action, evidence an observable build-up, and tend to be of relatively long duration, whereas disasters tend to be more sudden, less predictable, caused by natural forces, and generally shorter in duration (Tarlow, 2011; Hidalgo, 2015). Disasters are often defined as high-severity events, and they are seldom frequent (Kuto \& Groves, 2004; Ural, 2015; Agyeman et al., 2019). Crises in the tourism industry can take many shapes and forms, inter alia deadly disease outbreaks, terrorism, acts of nature, such as hurricanes or earthquakes, or a jet crashing into a hotel, and vandalism (Tarlow, 2011). Tarlow (2011, p. 2) posits that "the tourism risk manager must be well versed with knowledge on the potential crisis, and the probability of the crisis occurring and must have a plan ready to attempt to prevent the crisis before it occurs".

Pennington-Gray and Schroeder (2013), in discussing safety and security risks, suggested seven types of perceived risk for tourists, namely crime, disease, physical challenges, equipment failure, weather, cultural barriers, and political crises. A cardinal 
component of risk management, therefore, is to spearhead communication and consultation among the stakeholders. Risk communication and consultation has to be undertaken at each stage in the process, so as to ensure that all the stakeholders involved contribute to the tourism risk management process (Moreira, 2007; Tarlow, 2011; Ural, 2015). Another important component of risk management is the monitoring and reviewing activity concerned. The component helps to ensure continual improvements and the relevance of the tourism risk management process (Granger, 2000; Yang \& Nair, 2014). Ultimately, risk management processes must identify, analyse, evaluate, treat, monitor and review risks to the tourism destinations (Figure 1).

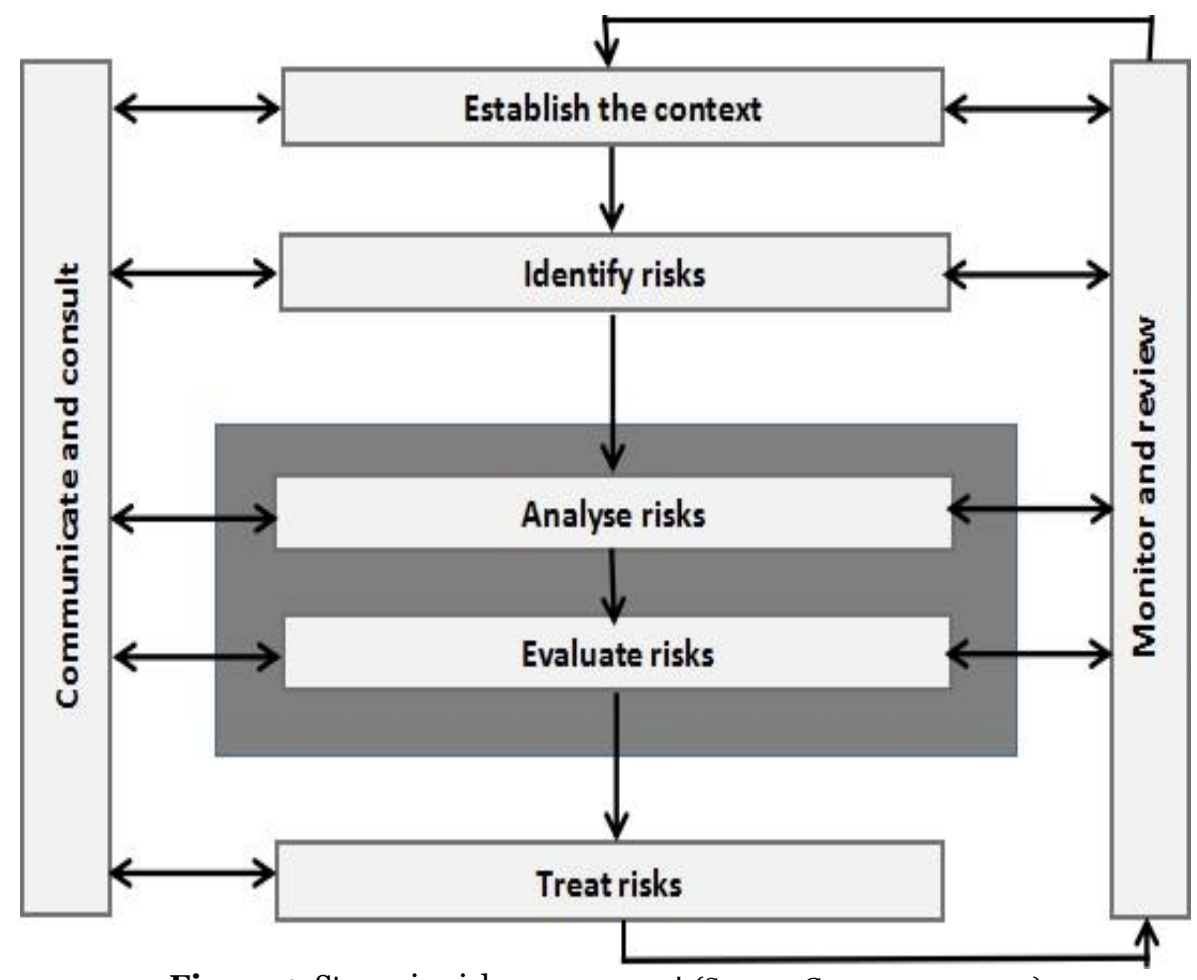

Figure 1. Stages in risk management (Source: Granger, 2000: 20)

Although often ignored in tourism risk management, how the various subsectors in the tourism industry demand different risk management scholarship and practice are important. A clear example of an attempt made to fill the existing knowledge gap, in the above respect, was performed by Bentley et al. (2004). The researchers examined the parameters of the New Zealand tourism industry to establish priorities for intervention, so as to reduce adventure tourism risk, and so as to identify the existing client injury control measures, with the view to establishing guidelines for the development of effective adventure tourism safety management systems. Agyeman et al (2019) maintain that sites with mountains and coasts are likely to be more vulnerable than are those that depend on cultural, or historical, attractions. In addition, risk management in tourism, especially in Africa, is often an ad-hoc activity for addressing what is often catastrophic and cataclysmic events (Eshun, 2011). Bentley et al. (2004), thus, caution tourism risk managers to focus on both the minor (e.g. slips, trips and falls), as well as the catastrophic, events. Hidalgo (2015) also cautions that, with the ascendance of 
agritourism, enotourism and ecotourism in the rural areas, there is an urgent need to build the capacity of especially the local communities in addressing climate change impacts on their livelihoods and properties, as well as on the natural environment. Some of the major crises that have occurred in the twenty-first century have had ramifications for tourism. For instance, Regmi and Walter (2017) show that a massive earthquake of 7.6 magnitude hit central Nepal on 25 April 2015, with it being followed by an aftershock of 6.8 magnitude on May 12. The occurrence killed about 9000 people, injured about 23 ooo, and affected one-third of Nepal's population of 28 million people (National Planning Commission, 2015). Another instance is the case of the Pacific Island countries.

The World Bank (2006) reported the occurrence of 207 major natural disasters (of which 157 were windstorms) between 1950 and 2004 in the region. The disasters concerned affected about 3.5 million people in the region, with an economic damage cost of over US $\$ 6.5$ billion. Also, more recently, the 1990s were believed to have endured disaster damage of around US\$2.8 billion in the South Pacific (World Bank, 2006). In the Maldives, the combined direct and indirect costs to tourist resorts, and the loss of government revenue from reductions in the number of tourist arrivals as a result of the 2004 Indian Ocean tsunami, were estimated to exceed US\$300 million (Becken et al., 2014).

Two broad categories of tourism-related crisis exist. The first category includes those crises that are beyond the control of the managers, the politicians and the policymakers (e.g. natural disasters and sudden global economic events). The second category includes those crises that are marked by poor management in tourism development, and the destruction of the existing infrastructure, due to fire, war, terrorism and political upheavals (COMCEC Coordination Office, 2017). Currently, some of the attempts that have been made to address the nexus of tourism and risk include the UNWTO Toolbox for Crisis Communications, the UNEP Climate Change Adaptation and Mitigation in the Tourism Sector, and the UN Tourism and Disaster Risk (PATA, 2011; Kanlayanasukho, 2014). The above notwithstanding, the impacts of crises on tourism are often silent in terms of risk management assessments undertaken at tourism sites, and more so at the ecotourism sites situated in the developing countries (Regmi \& Walter, 2017). Regmi and Walter (2017) note further that, despite the devastating nature of Nepal's earthquake in 2015, the National Planning Commission Post-Disaster Needs Assessment sidelined the tourism sector, and no assessment of the earthquake's impact on ecotourism has yet been undertaken.

Noteworthily, destination branding and risk management are regarded as being coterminous (Qu et al., 2011). Many authors posit that destination branding is ineluctably intertwined with a destination's competitiveness in the marketplace, since the existing destinations are becoming replaceable, due to increasing competition from new and emerging destinations worldwide (Goeldner \& Ritchie, 2003; Assaker et al., 2011). Indeed, destination branding becomes a key strategy after crises have occurred at sites, since the occurrences often affect a destination's image, in terms of the evoked set of actual and potential visitors (Qu et al., 2011; Angelkova et al., 2012). Hajibaba et al. (2016), showed how the Bali nightclub bombings of 2002 resulted in a 50\% drop in the number of tourist arrivals in the six months following the attacks, but gradually the destination is once more gaining market share, due to successful rebranding.

\section{MATERIALS AND METHODS}

The current study used a cross-sectional study design and a mixed methodological approach. 'Risk', as a term, is embedded within quantitative-related paradigm, with it often sidelining qualitative studies (Korstanje, 2011; Gozner et al., 2017; Ilieș et al., 2018; 2019; Lincu et al., 2018; Deac \& Gozner, 2019;). However, the constructivists posit that 
risk is socially constructed and that it is interpreted differently across varying social structures and cultures (Yang \& Nair, 2014). Thus, the current study employed the mixed-methodological approach to allow for the undertaking of a nuanced investigation, as the strength of one approach can cover up for the weakness in another (Eshun, 2011; Manful \& Eshun, 2015). The study population was drawn from Wechiau and Larabanga, which are the study communities that host the Wechiau Hippo Sanctuary (WHS) and the Mole National Park (MNP), respectively (Figure 2)

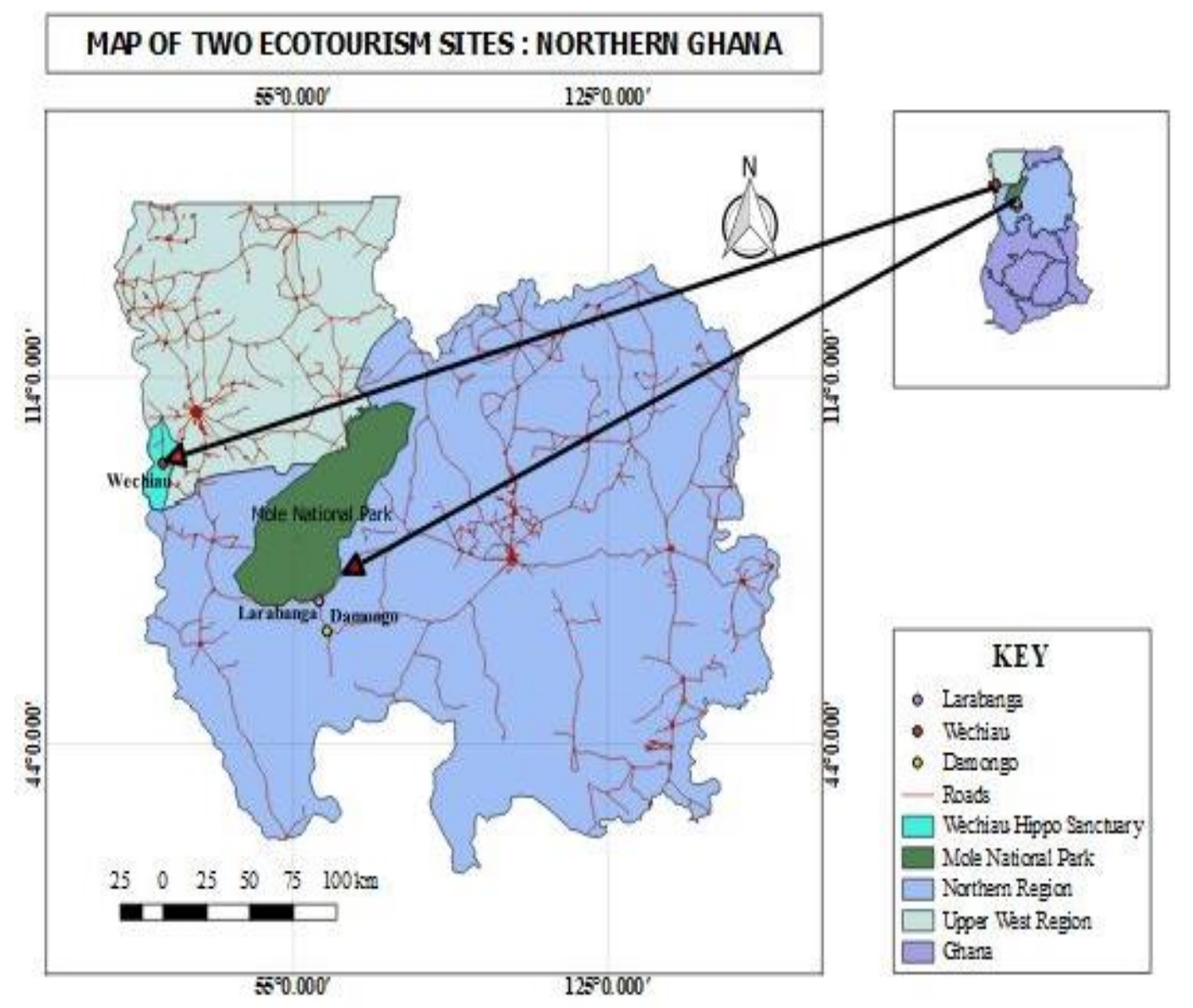

Figure 2. Map of Ghana (Source: Researchers' construct, 2020)

The WHS was initiated by the local community in 1999, which consists of a $40 \mathrm{~km}$ stretch down the length of the Black Volta River. In terms of biodiversity, the site is a habitat to bats, chameleons, hedgehogs, lizards snakes and over 200 species of birds. Hippos are the flagship species at the Sanctuary (Wildlife Division, 2000). Of the 17 reviews at TripAdvisor on the Sanctuary as at December 2019, 47.1\% indicated excellent ecotourism experience, $\mathbf{1 7 . 6 \%}$ very good, $35.3 \%$ average and none being poor.

The site is an excellent location for bird watching, village tours, river safaris, and nature walks (Wildlife Division, 2000; Eshun, 2011). The MNP is close to Damongo, the District capital of Larabanga in the Savannah region of Ghana. The Park is the largest of Ghana's national parks and covers $4,840 \mathrm{kms}^{2}$ of undulating terrain in the northern part 
of the country. The vegetation is pristine Guinea Savanna with gallery forests along the rivers and streams. Some 742 plant species are represented in the Park. Furthermore, the Park contains 93 mammal species, 33 reptile species, nine species of amphibians and about 300 species of birds. Large animals include the elephant, buffalo, roan antelope, kob, hartebeest, waterbuck, lion, leopard, hyena, four primate species and crocodiles. About 6oo elephants are estimated to live in the Park (Wildlife Division, 2020).

Of the 124 reviews on MNP at TripAdvisor as at December 2019, 50.0\% indicated excellent ecotourism experience, $32.3 \%$ very good, $16.1 \%$ average and only two (1.6\%) reviewers indicated a poor experience. While Kakum National Park enjoys high visitorship numbers in southern Ghana, MNP is the most popular ecotourism site in northern Ghana (Wildlife Division, 2000). The convenience technique was used to derive information from the residents by means of the administering of semi-structured questionnaires. Churchill and Brown (2004) note that obtaining an accurate sample size in a study relies on the nature of the population, and on the purpose of the study.

The quantitative facet of the study involved 210 people as the sample size, with 105 being selected from each of the two categorised study areas. The purposive sampling technique was employed to select the experts required for the study. Through the conducting of interviews with the experts, the qualitative data were collected. The key stakeholders interviewed included the site managers from the two ecotourism sites, four officers from the Ghana Tourism Authority (GTA), and an officer each from the Environmental Protection Agency, NADMO and the Forestry Commission. Each interview took between 30 to 55 minutes. Following ethical standards as espoused by Manful and Eshuh (2015), informed consent was sought from all the interviewees before any audiorecording was done. The data collected from the survey were processed using descriptive and inferential statistics, with the aid of SPSS version 25. The tools used included correlation and frequency, and the results were presented in tables and charts. The qualitative data were thematically analysed (Eshun, 2011; Mkono, 2013; Eshun, 2014).

\section{RESULTS DISCUSSIONS}

\section{Sociodemographic data of the respondents}

Of the 210 respondents involved in the study, 105 were selected each from Wechiau and Larabanga, which are the leading local communities for WHS and MNP, respectively. The data gathered from Mole revealed that $43 \%$ of the respondents were women, whereas, in Wechiau, 42\% were women. The 2010 population census shows that there were 20681 men and 20499 women in Mole, which reflected the percentage of males to female respondents. Also, the 2010 population census estimated a ratio of $52 \%$ men to $48 \%$ women to reside in Wechiau (Ghana Statistical Service, 2010). In both areas, the data revealed a relatively young population, with $38 \%$ and $47 \%$ of the respondents in Mole and Wechiau, falling in the age range of 29 to 39 years respectively. The educational level in both areas was relatively low, with $23 \%$ and $46 \%$ of the respondents at Mole and Wechiau respectively, holding only secondary school education certificates.

Also, significant to the study was that majority of the respondents have resided in the study communities for more than five years, and therefore all things being equal, were well-informed to provide rich data for addressing the study objectives. In addition, the level of unemployment in Mole was alarming, with 21\% of the respondents being jobless, which explained why some 30\% of the respondents in Mole earned no income. Also disapprovingly, the percentage of workers earning less than 100 Cedis per month constituted a relatively large proportion, with the majority of such persons being married and resident in the community for longer than five years. In Wechiau, 15\% of the respondents received less than 100 Cedis per month (Table 1). 
Table 1. Sociodemographic characteristics of the respondents (Data source: Fieldwork, 2018)

\begin{tabular}{|c|c|c|}
\hline Characteristics & $\begin{array}{c}\text { \% of responses from } \\
\text { Mole n=105 }\end{array}$ & $\begin{array}{l}\text { \% of responses from } \\
\text { Wechiau n=105 }\end{array}$ \\
\hline $\begin{array}{l}\text { Sex } \\
\text { Male } \\
\text { Female }\end{array}$ & $\begin{array}{l}57 \\
43\end{array}$ & $\begin{array}{l}58 \\
42\end{array}$ \\
\hline $\begin{array}{l}\text { Age (in years) } \\
18-28 \\
29-39 \\
40-49 \\
50<\end{array}$ & $\begin{array}{c}46 \\
38 \\
16 \\
0\end{array}$ & $\begin{array}{l}37 \\
47 \\
8 \\
8\end{array}$ \\
\hline $\begin{array}{l}\text { Occupation } \\
\text { Farmer } \\
\text { Herder } \\
\text { Unemployed } \\
\text { Civil servant } \\
\text { Teacher } \\
\text { Trader } \\
\text { Driver } \\
\text { Automechanic } \\
\text { Guard } \\
\text { Carpenter } \\
\text { Nurse } \\
\text { Traditional leader } \\
\text { Student }\end{array}$ & $\begin{array}{c}4 \\
4 \\
21 \\
8 \\
11 \\
34 \\
4 \\
2 \\
3 \\
1 \\
0 \\
0 \\
8\end{array}$ & $\begin{array}{c}5 \\
3 \\
12 \\
9 \\
21 \\
26 \\
0 \\
0 \\
0 \\
0 \\
12 \\
2 \\
10\end{array}$ \\
\hline $\begin{array}{l}\text { Educational status } \\
\text { Basic } \\
\text { Secondary } \\
\text { Tertiary } \\
\text { Uneducated }\end{array}$ & $\begin{array}{l}55 \\
23 \\
11 \\
11\end{array}$ & $\begin{array}{c}22 \\
46 \\
25 \\
7\end{array}$ \\
\hline $\begin{array}{l}\text { Length of stay } \\
<1 \text { year } \\
\text { Between } 1 \text { and } 5 \text { years } \\
>5 \text { years }\end{array}$ & $\begin{array}{c}4 \\
3 \\
93\end{array}$ & $\begin{array}{l}13 \\
21 \\
66\end{array}$ \\
\hline $\begin{array}{l}\text { Income generation } \\
\text { (per month, in Cedis) } \\
>100 \\
100-400 \\
>500 \\
\text { No income }\end{array}$ & $\begin{array}{c}35 \\
31 \\
4 \\
30\end{array}$ & $\begin{array}{c}15 \\
68 \\
7 \\
10\end{array}$ \\
\hline
\end{tabular}

Table 1 shows statistics giving Wechiau a slight edge over Mole, which can be seen in the level of income of those employed. Also, 68\% of the Wechiau respondents earned between 100 and 400 Cedis per month, which surpassed the same earning level at Mole (31\%). Furthermore, in Mole, 30\% of the respondents earned no income, compared to $10 \%$ of the respondents at Wechiau. In addition, $4 \%$ and $7 \%$ of the respondents in Mole and Wechiau respectively earned over 500 Cedis per month. The lack of personal development and growth could have been the underlying factor for the reason for the relatively low extent of development in the communities.

\section{NGOs and their roles in ensuring ecotourism sustainability}

Ecotourism sustainability involves the taking of much effort by the stakeholders within the industry, of which one is the NGOs (Belsky, 1999; Tosun, 2000). The NGOs, according to the site manager at WHS, had done well in using tourism as a medium for combating some of the economic challenges faced by the local communities. When asked whether the NGOs conducted activities in Wechiau and Mole, all the respondents 
answered 'yes', making the affirmative vote $100 \%$ for both areas. The study assessed the effectiveness of the roles played by NGOs in terms of the issues of sustainability related to both the study areas (Figure 3). Eshun (2011) argues that NGOs contribute to ecotourism sustainability, especially where they work concurrently with local community members. For instance, an NGO like Agriculture and Natural Resources Management (AGRM), which operates in collaboration with the Canadian government, is involved in treeplanting projects, in providing good drinking water to the locals, and in fencing the Sanctuary. The supply of potable water can fluctuate widely in the study areas concerned.

Furthermore, the NGOs, such as USAID and World Vision, are very active in providing most of the social intervention schemes in the form of financial support, like scholarships for students who distinguish themselves, and social infrastructure, like the construction of Community-Based Health Planning and Services (CHPS), compounds in Larabanga and Damongo, as well as market centres and the rehabilitation of health and school facilities. In Wechiau, at the time of the current study, WindRock International was helping to equip women with skills that helped them to produce Shea butter and other products that they intended to sell to the visitors. The study found that the direct impact of NGOs on ecotourism was the reality in Wechiau, whereas Mole enjoyed other interventions, though not ones that were directly related to ecotourism. There exist some level of interesting research on ecotourism development in Ghana attesting to the fact that the benefits from CBEs tend to be higher than that which accrue from SLEs to local communities (Eshun, 2011; Agyeman, 2013; Amoako-Acheampong, 2013).

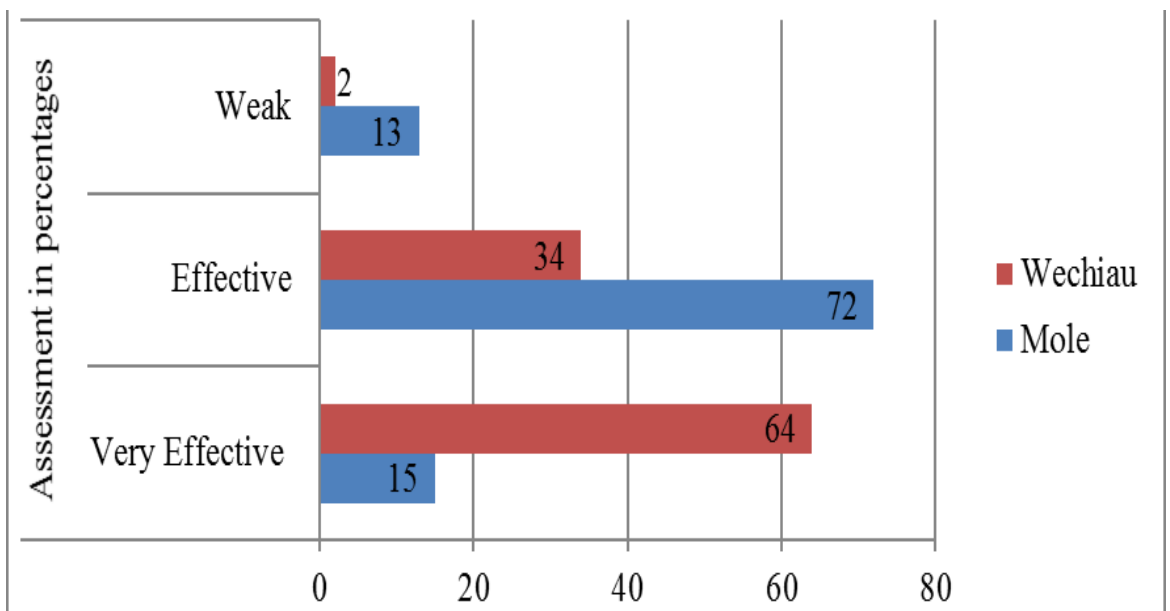

Figure 3. Assessment of the roles played by the NGOs in the study areas concerned (Source: Fieldwork, 2018)

\section{Community participation in ecotourism sustainability}

Of the 105 respondents in Mole, $18.1 \%$ admitted to being stakeholders in tourism operations in the park, $5.7 \%$ were uncertain about their stake in tourism business or operations in the community, and as many as $76.2 \%$ of the respondents categorically stated that they had no stake in ecotourism management and development, which also affected their attitude toward ecotourism and its sustainability in the community. A weak linear relationship of $(\mathrm{r}=0.326)$ was found to exist between the attitude of the respondents and their view on their stake in the ownership of tourism in the Mole community. The implication was that the attitude of the respondents toward tourism development depended on whether or not they perceived themselves as the owners of 
tourism ventures. The presence of a weak linear relationship implies that other factors were affecting the attitude of the respondents towards ecotourism development and sustainability, than just having a stake in the ownership, or not. Eshun (2011) show that some local residents around ecotourism sites in Ghana take their direct or indirect employment as a form of involvement. Furthermore, the study showed that $15.2 \%$ of the 105 respondents admitted to receiving some form of benefit that influenced their attitude towards ecotourism development, and some $84.8 \%$ indicated otherwise. Based on the minimal benefits accruing to community members at Larabanga, the Pearson Correlation establishes a weak positive relationship between community members' attitude towards ecotourism development at MNP (see Table 2). The above re-establishes the cogency of the earlier argument that economic benefits had the highest influence on the locals in terms of biodiversity stewardship (Tosun, 2000; Eshun, 2011; Fennell, 2014; Eshun \& Tagoe-Darko, 2015; Romero-Brito et al., 2016; Eshun \& Tichaawa, 2019).

Table 2. The relationship between community members'

attitude towards ecotourism development (Data source: Fieldwork, 2018)

\begin{tabular}{|c|c|c|c|}
\hline \multicolumn{4}{|c|}{ Correlations } \\
\hline & & $\begin{array}{l}\text { Do you see the community } \\
\text { as being the stakeholders } \\
\text { in terms of ownership? }\end{array}$ & $\begin{array}{l}\text { What has been the } \\
\text { attitude of the community } \\
\text { members towards } \\
\text { ecotourism development } \\
\text { at the site? }\end{array}$ \\
\hline \multirow{3}{*}{$\begin{array}{l}\text { Do you see the } \\
\text { community as the } \\
\text { stakeholders in terms } \\
\text { of ownership? }\end{array}$} & $\begin{array}{l}\text { Pearson } \\
\text { correlation }\end{array}$ & 1 & $.326^{* *}$ \\
\hline & Sig. (two-tailed) & & .001 \\
\hline & $\mathrm{N}$ & 105 & 105 \\
\hline
\end{tabular}

The community could not be sidelined on the basis of their poor educational background, or on that of their lack of knowledge regarding ecotourism since they were well situated to achieve successful ecotourism in Mole. The findings were very different in relation to Wechiau, in relation to which $98 \%$ of the respondents admitted to being a part of the stakeholders in ecotourism, with only two replying in the negative, on the basis that they, as individuals, were not consulted when decisions were made. The $98 \%$ of the respondents at Wechiau acknowledged that they felt the impact of ecotourism directly, due to the position of WHS as a CBE initiative. In addition, the study teased out the relationship of community members to ecotourism in their domain.

Copious literature posits that when synergy exists among the various stakeholders, ecotourism is able to contribute to sustainably to conservation and local well-being (Honey, 2008; Fennell, 2014; Eshun \& Tichaawa, 2019). A prime reason for setting up the Tourism Management Committees, especially at the CBE sites in Ghana, was to ensure that the local interests were taken on board, and to ensure that the issue of directing economic benefits toward local well-being were not sidelined (Eshun \& Tagoe-Darko, 2015; Eshun et al., 2016). The manager at WHS stated:

"Tourism has thrived in Wechiau because the people understand the chiefs, management and the other stakeholders. We encourage idea cross-fertilisation, and the rapport that now exists is due to transparency . and accountability created that."

The above statement notwithstanding, the traditional authority in the Wechiau area sometimes marginalised the other subgroups (i.e. the farmers and fishermen in the area were seen as immigrants, and, therefore, had less of a stake in biodiversity conservation 
and in the benefits that should have accrued to them from the ecotourism based on the Sanctuary (Adjewodah \& Beier, 2004). To ensure full participation in ecotourism, the different groups within the communities concerned, including the women, men and youth, require representation on the Tourism Management Committee (Belsky, 1999; Tosun, 2000; Scheyvens \& Momsen, 2008; Eshun, 2011).

\section{Government's role in ecotourism marketing and mechanisms}

Tourism development in Ghana has largely been championed by the Ministry of Tourism, the GTA and the Forestry Commission (Amoako-Acheampong, 2013). Currently, the GTA remains the National Tourism Organisation, largely responsible for the marketing of tourism sites across the country (Eshun, 2014). The Forestry Commission, especially through its two organs - the Forestry Service and the Wildlife Department - are in charge of the ownership and development of the especially prominent ecotourist attractions across the country (Mensah \& Adofo, 2013). Eshun (2011, p.24) argues that tourism development in Ghana has largely focused on managing the national parks and the slave castles. In the above respect, a respondent forcefully noted:

"Ghana has lost about 32 tourist sites over the last two decades, due to three main factors: the absence of effective marketing strategies, ineffective risk management policies, and institutional weakness in the area of development and maintenance. The existing 34 tourism attractions, including ecotourism sites, will reduce so far as these three factors mentioned are not tackled."

The current study showed that $53.3 \%$ of the sample of respondents indicated that the tourists learned about the ecotourism sites through the Internet. However, disparities were present in the results. At Mole, $40.9 \%$ of the respondents noted that there was no government initiative to market the site, while $59 \%$ agreed partially with the above. Also, 40.3\% (of $n=62$ ) further stressed that the community members did nothing to market the Park. At Wechiau, many respondents (77.1\%) indicated that the government was not involved in the marketing of the site, whereas some (21.0\%) said that the government was involved, and very few (2.9\%) were indifferent on the issue. The disparity between the two sites confirmed what Eshun (2014) points out as being the two main types of ecotourism in Ghana, namely state-led ecotourism (SLE) and community-based ecotourism (CBE).

Table 3. Major risks confronting ecotourism in Mole (Data source: Fieldwork, 2018)

\begin{tabular}{|c|l|c|c|}
\hline \multicolumn{2}{|c|}{ Risks } & Frequency & Percentages \\
\hline \multirow{5}{*}{ Valid } & Land encroachment & 12 & 9.5 \\
\cline { 2 - 4 } & Logging & 45 & 35.7 \\
\cline { 2 - 4 } & Extreme weather & 19 & 15.1 \\
\cline { 2 - 4 } & Poaching & 23 & 18.3 \\
\cline { 2 - 4 } & Bushfires & 21 & 16.7 \\
\cline { 2 - 4 } & Robbery/Crime & 6 & 4.7 \\
\cline { 2 - 4 } & Total & $\mathbf{1 2 6}$ & $\mathbf{1 0 0 . 0}$ \\
\hline
\end{tabular}

Consequently, depending on whether an ecotourism site is managed by the government through the Wildlife Division and Forestry Service, or through the Tourism Management Committees, as in the case of the CBE, their corporate strategies differed greatly. The MNP, which is a leading SLE, draws much commitment and working capital from the government. The GTA website markets MNP, alongside designing and distributing brochures in its offices nationwide. Despite some efforts being made at marketing the SLE in Ghana, 42\% of the respondents concluded that the government's efforts through the National Tourism Organisations having to do with ecotourism 
marketing in the country were totally inadequate. Earlier research than the present implies that the government, particularly through the GTA, must strengthen its marketing strategies at all ecotourism sites across the country (Eshun \& Tagoe-Darko, 2015).

Hunters are the main culprits, who deliberately, or through carelessness, set some portions of the Park or its boundaries on fire, with the concomitant biodiversity loss. A respondent explained:

"Some deliberately set fires around the edges of the Park to vent their anger at the Park authorities. Some have not been treated fairly, because they had to evacuate their farming lands for the creation of the Park without compensation."

Land encroachment was also found to be a problem, with, for example, $9.5 \%$ of the risks being due to those who defiantly bought plots of land that had been legally allocated to the Park authority, therefore generating land ownership disputes. The encroachment of parks and reserves is increasingly becoming a problem in Ghana, especially with the rapid urbanisation (Adjewodah \& Beier, 2004). The rapid urbanisation has also resulted in high demand for wood, especially for fuel and furniture (35.7\%). Poaching registered $18.3 \%$ of the risks confronting the Park. Some poachers had suffered fatal attacks by the animals, as can be seen in the following statement:

"Four persons were killed in 2016 and 2017 by buffalos at the Park. But the fear is, if these act[s] of poaching and logging are not prevented, the Park will soon become a wasteland, unsuitable for ecotourism. These illegal acts will continue unless the silent and weak institutions start to bite."

Interestingly, the literature on tourism risk management has yet to engage seriously in how climate change affects tourism (Moreira, 2007; DeChazal \& Rounsevell, 2009). Hidalgo (2015), researching the ramifications of climate change on the agriecotourism businesses in the Philippines, argued that climate change will continue to affect both current and future tourism demands worldwide. For example, the temperatures between November and March at Mole contribute to the low visitorship to the Park, with it remaining a risk (15.1\%). Beyond the above, some $4.7 \%$ of the respondents agreed that the tourists to the areas concerned were prone to much criminal behaviour, with highway robbery being mentioned as a major factor. Travelling the road from Larabanga to Fofulso, there were no police barracks along the almost $140 \mathrm{~km}$ stretch of road to enforce the key measures put in place to minimise the attendant risks (Table 4).

Table 4. Measures to manage risks at MNP (Data source: Fieldwork, 2018)

\begin{tabular}{|c|c|}
\hline Risk & Management mechanism \\
\hline Bush burning & $\begin{array}{l}\text { Fining of the culprits } \\
\text { - A satellite disk over the entire Park to monitor activities therein }\end{array}$ \\
\hline Poaching & $\begin{array}{l}\text { - A satellite disk to monitor activities in and around the Park } \\
\text { - A 24-hour security patrol service in and around the Park } \\
\text { - Prosecuting of the culprits to serve as a deterrent to potential culprits }\end{array}$ \\
\hline $\begin{array}{l}\text { Land } \\
\text { encroachment }\end{array}$ & $\begin{array}{l}\text { - Education regarding land markings } \\
\text { - The taking of legal measures to protect the Park's boundaries } \\
\text { community members } \\
\text { - Compensations paid to those affected } \\
\text { - Education in general }\end{array}$ \\
\hline Logging & $\begin{array}{l}\text { - The deployment of park guards to keep the forest safe } \\
\text { - } \\
\text { - } \\
\text { Education of those intending to log, or who are caught in the act of logging } \\
\end{array}$ \\
\hline
\end{tabular}


Also, on the issue of the highway robbery of, and extortion from tourists, the respondents were not able to suggest specific preventative measures, except to depend on the central government to protect them. At the time of the study, $71(67.6 \%)$ of the respondents did not think that the community had to do anything to manage the risks that threatened to uproot the sustainability of ecotourism, while $11(10.4 \%)$ thought that it did, and 23 (22.0\%) were uncertain about the issue. Interestingly, none of the respondents mentioned the raiding of farms by elephants as a source of conflict between themselves and management, although there exists some amount of literature in Ghana attesting to this (Adjewodah \& Beier, 2004; Eshun, 2011; Eshun \& Tonto, 2014).

A similar study at the WHS showed that 10 (6.6\%) of the respondents pointed out that tribal conflict was a major risk to the sustainability of the Sanctuary (Table 5). This addition was totally absent in the result from MNP. There are more migrants to the Weichiua, as compared to Mole and this might account for the conflict among tribes. Also, both MNP and WHS have issues of illegal logging taking place at the locations, which therefore demands that management and the local communities devise the right strategies to curb the trend. Also, the issue of poaching registered a lower percentage at WHS. Two factors are immediately accountable for this result. First, there is a huge community reverence for the hippos at WHS, which may have positive stewardship towards the other faunal species in the Sanctuary. Secondly, there is more access to protein sources around the Wechiau area because of especially the Black volta.

Table 5. Major risks confronting ecotourism at WHS (Data source: Fieldwork, 2018)

\begin{tabular}{|c|l|c|c|}
\hline \multicolumn{2}{|c|}{ Risks } & Frequency & Percentages \\
\hline \multirow{5}{*}{} & Land encroachment & 14 & 9.3 \\
\cline { 2 - 4 } & Illegal Logging & 71 & 47.0 \\
\cline { 2 - 4 } & Extreme weather & 22 & 14.6 \\
\cline { 2 - 4 } & Poaching & 10 & 6.6 \\
\cline { 2 - 4 } & Bushfires/Wildfires & 21 & 13.9 \\
\cline { 2 - 4 } & Tribal Conflicts & 10 & 6.6 \\
\cline { 2 - 4 } & Robbery/Crime & 3 & 2.0 \\
\cline { 2 - 4 } & Total & $\mathbf{1 5 1}$ & $\mathbf{1 0 0 . 0}$ \\
\hline
\end{tabular}

Furthermore, interviews were conducted with the manager and staff of the WHS, on ways of addressing risks at the Sanctuary. Some of the risk measures are presented in Table 6.

Table 6. Measures to manage risks at WHS (Data source: Fieldwork, 2018)

The rangers: The Park management team had employed some of the youth to patrol the Park during the day, and sometimes at night. The activities of the so-called 'Park Rangers' were usually limited to the day, because of the distance from the main township to the site, and also because of the absence of power supply between the community and the site. Street lights were also not available.

Orientation: The community members were orientated to appreciate the presence of the hippos. Their orientation took two main forms: the 'Kaka Festival', with 'Kaka' meaning 'hippos' in the local language; and community meetings, at which the views of the community members were voiced. The adoption of such approaches orientated the local community members to see themselves as the stewards of the surrounding ecosystems.

Fence construction: In partnership with the Canadian government, a fence was being built around the Sanctuary, which would prevent especially illegal fishermen and poachers from pursuing their unlawful activities.

Conflict resolution and possible prevention: The government had adopted the use of such alternative dispute resolution mechanisms as negotiation to bring the aggrieved groups to consensus. In terms of crime minimisation, the visibility of the police was increased through the patrolling of the police team, and through the erection of police barriers along the major community roads. 
Unlike in the case of the fauna in Mole, the community members in Wechiau believed that the hippos in the Sanctuary had saved them in their most recent battle with a particular tribe from Burkina Faso. Thus, they saw the hippos as animals that kept them safe. Consequently, the sustainability of the animals meant life and the absence of death, and the community members were intrinsically inclined to protect them. Eshun and Tonto (2014) show that the threats to the monkeys (i.e. the Mona and Black and White Colobu, the flagship species), at Boabeng-Fiema Sanctuary, are minimal, because of the locals' reverence for them as children of gods.

\section{Local communities' understanding of ecotourism sustainability}

The existing plethora of research on ecotourism (Weaver \& Lawton, 2007; Scheyvens \& Momsen, 2008; Rusko \& Prochazkova, 2011; Eshun \& Tagoe-Darko, 2015; Regmi \& Walter, 2017; Ramón-Hidalgo et al., 2018) has largely been silent on how the local communities define and interpret the concept of sustainability in relation to ecotourism development. The study, therefore, asked the respondents to define the meaning of 'ecotourism sustainability' (Figure 4). A total of 229 responses were obtained from the two study communities, of which balance for local development and biodiversity conservation registering the highest percentage of $31 \%$.

Figure 3. Respondents' understanding of the concept of ecotourism sustainability (Source: Fieldwork, 2018)

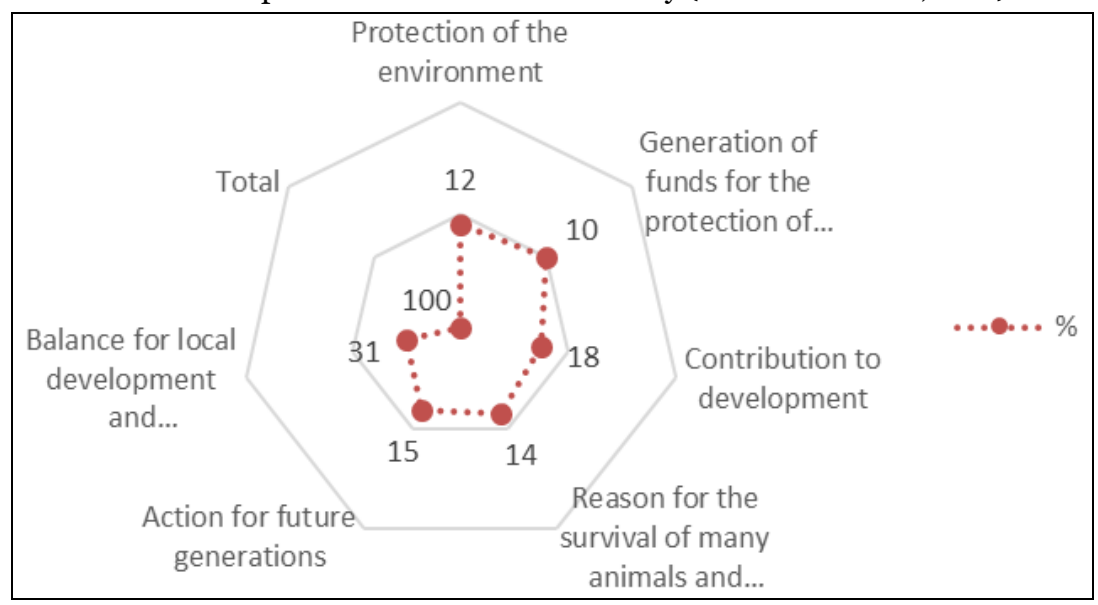

Table 7. The relationship between the educational level of the respondents and their understanding of ecotourism sustainability (Data source: Fieldwork, 2018)

\begin{tabular}{|c|l|l|}
\hline & Pearson correlation & 1 \\
Educational level & sig. (two-tailed) & .039 \\
& N & 105 \\
\hline What is your understanding of & Pearson correlation & $-0.201^{*}$ \\
'ecotourism sustainability'? & sig. (two-tailed) & .039 \\
N & 105 \\
\hline
\end{tabular}

The locals have a fair understanding of the meaning of sustainability, at least in theory. Due to the relatively high educational level Wechiau, the study conducted a Pearson Correlation, which established a relationship between community members' educational level and their understanding of ecotourism sustainability (Table 7). The result of $r=-0.21$ showed that the level of education of a respondent should not be 
taken as an indication of their level of understanding of the nature of ecotourism sustainability. The existing research attests to an understanding beyond the highest educational level attained, in view of the special orientation of community members that help them to understand and to gain skills that should help them contribute to sustainability (Eshun, 2011; Hidalgo, 2015; Ramón-Hidalgo et al., 2018).

A number of legislative instruments promulgated in the last four decades have helped to manage, develop and conserve biodiversity in Ghana (Amoako-Acheampong, 2013; Mensah \& Adofo, 2013; Ramón-Hidalgo et al., 2018). Most of the statutes are sector-based, and they can be conflicting, inchoate, obsolete and unenforceable (Eshun, 2014). Currently, Western scientific knowledge underpins global biodiversity conservation (Hens, 2006; Eshun, 2011, 2014; Eshun \& Tagoe-Darko, 2015). Dumbe et al. (2018), therefore, argue convincingly that ecotourism 'experts' must avoid seeing local people as lacking knowledge that could ultimately benefit ecotourism sustainability. As a point in case, whereas the tourists view the hippos at Wechiau as mere animals, the locals hold the belief that the hippos protect them from their enemies. Consequently, many proponents of ecotourism sustainability have argued for creating platforms that allow for the host community to bring their various interests and views on board in pertinent decision-making (Eshun, 2011; Rusko \& Prochazkova, 2011; Regmi \& Walter, 2017).

\section{Tourist inflow and relationship with the local communities}

The sustainability of ecotourism depends on the relationship that exists between the host and the tourist (Ramón-Hidalgo et al., 2018). In the current study, the responses that were received from the respondents showed that the respondents of the study areas were friendly towards the visitors. Over eighty percent $(83.8 \%)$ of the respondents at Mole indicated that the community members were friendly toward the tourists, with $16.2 \%$ stating that the community members were very friendly, which is a positive indication for ecotourism sustainability. However, $8.6 \%$ insisted that the tourists posed a threat for them, while $91.4 \%$ said that the tourists posed none. Similarly, in Wechiau, $63.8 \%$ and $36.2 \%$ of the respondents stated that the community members were friendly and very friendly, respectively, toward the visitors.

At Wechiau, only $1.9 \%$ of the respondents said that the presence of the tourists posed a threat to their culture. They further indicated that they were sidelined in the management of the Sanctuary, which affected their interaction with the visitors there. In Mole, the data on the threats posed by the tourists were complex. The inflow of tourists to a destination is never static (Honey, 2008; Akama et al., 2011; AmoakoAcheampong, 2013; Fennell, 2014; Eshun \& Tichaawa, 2019). This said, data obtained for the study showed that since 2001, tourism inflows had consistently exceeded 900 tourists in both of the two study areas. The manager at MNP stated:

"The increase in 2008 was due to the African Cup of Nations hosted in Ghana. The Tamale Stadium hosted the Group D matches and brought a lot of football enthusiasts to the area. The years 2016 and 2017 were challenging, because of the severity of the harmattan and [because of] the closure of the Buipe and Yapei Bridges."

The outbreak of Ebola from 2014 onwards accounted for a fall in the number of visitors to the Park, especially in terms of its international visitors. In Wechiau, the figures for visitors have consistently been above 900 per year since 2004. Hidalgo (2015) argues that environmental factors determine the inflow of tourists, with such factors manifesting themselves in the form of natural disasters, the outbreak of disease, or weather conditions. Currently, at WHS during the dry season there is relatively higher numbers of international tourists visiting the Sanctuary, whereas midyear, between June and October, there are more domestic tourists visiting the site. 
Most of the tourists to the two ecotourism sites were found to be allocentric (Eshun, 2014; Eshun \& Tonto, 2014). However, among the domestic tourists, distance was regarded as a discouraging factor. From Accra to Wa is about $700 \mathrm{~km}$ via land, from Wa to Wechiau is about $22 \mathrm{~km}$, and from Wechiau to the Sanctuary is $18 \mathrm{~km}$ (total $740 \mathrm{~km}$ ), which tends to frustrate the average ecotourist. Table 8 shows the tourist inflow to WHS, along with the amount of revenue generated each year. The remarkable increase in the tourist inflow from 2005 to 2006 was due to the rebranding and development of the site, with financial support granted by the Canadian government.

Table 8. Tourist inflow and amount of revenue generation at Wechiau on a yearly basis (Data source: Fieldwork)

\begin{tabular}{|c|c|c|c|c|}
\hline Year & $\begin{array}{c}\text { Number of } \\
\text { International visits }\end{array}$ & $\begin{array}{c}\text { Number of } \\
\text { domestic visits }\end{array}$ & $\begin{array}{c}\text { Total number } \\
\text { of visits made }\end{array}$ & $\begin{array}{c}\text { Amount of revenue } \\
\text { generated (Cedis) }\end{array}$ \\
\hline $\mathbf{2 0 0 4}$ & 870 & 634 & 1504 & 8114.45 \\
\hline $\mathbf{2 0 0 5}$ & 391 & 550 & 941 & 5073.30 \\
\hline $\mathbf{2 0 0 6}$ & 1144 & 512 & 1656 & 7551.85 \\
\hline $\mathbf{2 0 0 7}$ & 1183 & 673 & 1856 & 11725.30 \\
\hline $\mathbf{2 0 0 8}$ & 1018 & 797 & 1815 & 15867.15 \\
\hline $\mathbf{2 0 0 9}$ & 1339 & 931 & 2270 & 25695.05 \\
\hline $\mathbf{2 0 1 0}$ & 1236 & 678 & 1914 & 14493.50 \\
\hline $\mathbf{2 0 1 1}$ & 825 & 759 & 1584 & 23300.00 \\
\hline $\mathbf{2 0 1 2}$ & 961 & 694 & 1655 & 21561.00 \\
\hline $\mathbf{2 0 1 3}$ & 965 & 943 & 1908 & 26484.80 \\
\hline $\mathbf{2 0 1 4}$ & 788 & 499 & 1287 & 23840.00 \\
\hline $\mathbf{2 0 1 5}$ & 459 & 364 & 823 & 15722.00 \\
\hline $\mathbf{2 0 1 6}$ & 344 & 419 & 763 & 23922.00 \\
\hline $\mathbf{2 0 1 7}$ & 567 & 350 & 917 & 40672.00 \\
\hline
\end{tabular}

From 2006 to 2010, the inflow of international tourists to the area was in the thousands. The highest was in terms of domestic tourism in 2009, with 931 tourists. From 2011, the numbers began to fall again, with the number of international visits falling back into the hundreds, with the major causes being the threat of an outbreak of Ebola in Africa, and the political tensions in the neighbouring countries, like Cote d'Ivoire.

In 2016, the numbers fell drastically, especially in terms of international visits, which was due to the severity of harmattan, which called for the cancelling of many flights. The above-mentioned factors lay further credence to the evidence that tourism products can be affected by externally induced disruption (Gabbatt, 2010; PATA, 2011).

\section{CONCLUSION}

In the face of the many risks and the poor biodiversity conservation principles concerned, there is a need to unravel the concept of sustainability in ecotourism, especially in the developing countries, where the concept is gaining more attention as a win-win strategy for purposes of biodiversity conservation and economic development (Yang \& Nair, 2014; Romero-Brito et al., 2016; Agyeman et al., 2019). Sustainability is a cardinal concept in terms of ecotourism-related scholarship (Honey, 2008; Kimbu \& Tichaawa, 2018; Ramón-Hidalgo et al., 2018). A number of ecotourism sites are either rapidly degrading, or have already been degraded (Fennell, 2014; Romero-Brito et al., 2016). The above has called for critical research into such issues as the branding and marketing of ecotourism sites, the community participation in ecotourism, the risks facing biodiversity, and the ecotourism sustainability concerned (Rogerson, 2015; Eshun \& Tonto, 2014; Yang \& Nair, 2014; Romero-Brito et al., 2016). 
Other works on ecotourism position community participation congruently with sustainability (Tosun, 2000; Scheyvens \& Momsen, 2008; Becken et al., 2014; Eshun \& Tonto, 2014). Building on the earlier studies undertaken in the same field, the work showed that the level of local participation in ecotourism was relatively low, especially at the MNP. Research has shown that the amount of local participation at the SLEs in Ghana tends to be relatively low (Amoako-Acheampong, 2013; Mensah \& Adofo, 2013; Eshun and Tagoe-Darko, 2015; Agyeman et al., 2019). In addition, the few benefits from both the SLEs and CBEs in Ghana have been the cause of disgruntlement among some fringe communities in Ghana (Agyeman, 2013; Eshun, 2014; Eshun \& Tagoe-Darko, 2015; Agyeman et al., 2019). Furthermore, the study shows that the nexus of risk management and ecotourism sustainability has no specific practices to help protect biodiversity and visitors. The existing risk management is not holistic and remains largely ad hoc in approach (with it often being initiated only when a disaster occurs). Currently, the risks facing the study sites include mostly logging, bushfires and poaching, as well as criminal activities. The study also shows that the marketing strategies at the study sites remain largely ineffective. Although hippos and elephants remain the flagship species of WHS and MNP respectively, the marketing strategies involved have yet to exceed the offering of such unique selling propositions that set the sites apart from other such sites in Ghana. In sum, further research can build on the empirical and theoretical outcomes of the study and employ Granger's (2000) proposed view of the stages in risk management, toward developing practical risk management strategies for sustainable ecotourism development in Ghana and beyond.

\section{REFERENCES}

Adjewodah, P. \& Beier, P. (2004). Working with traditional authorities to conserve nature in West Africa. African Conservation Telegraph, 1(2), 3-5.

Agyeman, Y.B. (2013). The role of local knowledge in sustaining ecotourism livelihood as an adaptation to climate change. Doctoral thesis submitted to the University of Waterloo.

Agyeman, Y. B., Yeboah, A. O., \& Ashie, E. (2019). Protected areas and poverty reduction: The role of ecotourism livelihood in local communities in Ghana. Community Development, 5o(1), 73-91.

Akama, J.S., Maingi, S. \& Carmago, B.A. (2011). Wildlife conservation, safari tourism and the role of tourism certification in Kenya: a postcolonial critique. Tourism Recreation Research, 36(3), 281-291.

Amoako-Acheampong, A. (2013). Ecotourism and local community development: a study of the Wechiau Community Hippopotamus Sanctuary in the Upper West Region of Ghana. MPhil thesis submitted to the University for Development Studies.

Angelkova, T., Koteski, C., Jakovlev, Z. \& Mitrevska, E. (2012). Sustainability and competitiveness of tourism. Procedia - Social and Behavioral Sciences, 44, 221-227.

Assaker, G., Vinzi, V. \& O'Connor, P. (2011). Examining the effect of novelty seeking, satisfaction, and destination image on tourists' return pattern: a two factor, non-linear latent growth model. Tourism Management, 32, 890-901.

Becken, S., Mahon, R., Rennie, H. \& Shakeela, A. (2014). The Tourism Disaster Vulnerability Framework: an application to tourism in small island destinations. Natural Hazards, 71(1), 955-972.

Belsky, J. (1999). Misrepresenting communities: The politics of community-based rural ecotourism in Gales Point Manatee, Belize. Rural Sociology, 64(4), 641-66.

Bentley, T.A., Page, S. \& Walker, L. (2004). The safety experience of New Zealand adventure tourism operators. Journal of Travel in the Mediterranean, 11, 280-286.

Churchill, G.A. \& Brown, T.J. (2004). Basic marketing research in education: a conceptual introduction. Longman, New York.

Deac, L.A., Gozner, M. \& Sambou A. (2019). Ethnographic Museums in the Rural Areas of Crișana Region, Romania Keepers of Local Heritage, Tradition and Lifestyle. GeoJournal of Tourism and Geosites, 27(4), 1251-1260.

DeChazal, J. \& Rounsevell, M.D.A. (2009). Land-use and climate change within assessments of biodiversity change: A review. Global Environmental Change 19, 306-315.

Dumbe, Y., Seebaway, Z.M. \& Eshun, G. (2018). The nexus of traditional ecological knowledge and ecotourism development: a case of Bobiri Forest and Butterfly Sanctuary, Ghana. African Journal of Hospitality, Tourism and Leisure, 7, 1-19. 
Eshun, G. (2011). Ecotourism Development in Ghana: A Postcolonial Study with Focus on Boabeng-Fiema Monkey Sanctuary and Kakum National Park. PhD Thesis. Universitity of Leicester. Unpublsihed.

Eshun, G.(2014). Towards the dual mandate of ecotourism in Africa: a comparative study from Ghana. African Insight, 44(3), 164-184.

Eshun, G. \& Tonto, J.N.P. (2014). Community-based ecotourism: its socio-economic impacts at Boabeng-Fiema Monkey Sanctuary, Ghana. Bulletin of Geography, Socio-economic Series, 26, 67-81.

Eshun, G. \& Tagoe-Darko, E. (2015). Ecotourism development in Ghana: a postcolonial analysis. Development Southern Africa, 32, 392-406.

Eshun, G., Adjei, P. O-W. \& Segbefia, AY. (2016). Ecotourism and Marketing Nexus: A Study at Bobiri Forest Reserve and Butterfly Sanctuary in Ghana. African Journal of Hospitality, Tourism and Leisure, 5 (2):1-10.

Eshun, G. \& Tichaawa, T.M. (2019). Reconsidering participation for local community well-being in ecotourism in Ghana. GeoJournal of Tourism and Geosites, 27(4), 1184-1200.

Fennell, D.A. (2014). Ecotourism. Routledge, New York, NY.

Gabbatt, A.. (2010). Volcanic ash cloud cost European business up to €2.5bn, http://www. guardian.co.uk/world/2010/apr/27/iceland-volcano-cost-business- europe/, accessed 28.04.2010.

Goeldner, C.R. \& Ritchie, J.R. (2003). Tourism principles, practices, philosophies. Wiley, Hoboken, NJ.

Gozner, M., Tătar, C.F., Stupariu, M. \& Măduta, F.M. (2017). Nature, Photography and Tourism in BihorVlădeasa Mountains (Romania). GeoJournal of Tourism and Geosites, Year X, Volume 20, OradeaGdansk, Romania-Poland, Editura Universităţii din Oradea.

Granger, K. (2000). An information infrastructure for disaster management in Pacific island countries. Australian Journal of Emergency Management. Autumn, 20-32.

Hajibaba, H., Boztug, Y. \& Dolnicar, S. (2016). Preventing tourists from cancelling in times of crisis. Annals of Tourism Research, 60, 48-62.

Harilal, V. \& Tichaawa, T.M. (2018a). Ecotourism and alternate livelihood strategies in Cameroon's protected areas. EuroEconomica, 37(2), 133-147.

Harilal, V. \& Tichaawa, T.M. (2018b). Community awareness and understanding of eco-tourism within the Cameroonian context'. In Van de Wald, A, Kotze, N, Barker, C \& Kruger, E (eds), Proceedings of the Biennial Conference of the Society of South African Geographers: 1 - 5 October 2018, University of the Free State, pp. 163-177.

Harilal, V., Tichaawa, T.M. \& Saarinen, J. (2019). Development without policy: Tourism planning and research needs in Cameroon, Central Africa. Tourism Planning and Development, 16(6), 696-705.

Hens, L. (2006). Indigenous knowledge and biodiversity conservation and management in Ghana. Journal of Human Ecology, 20(1), 21-30.

Hidalgo, H.A. (2015). Vulnerability assessment of agri-ecotourism communities as influenced by climate change. International Journal of Advanced Science Engineering Information Technology, 5(6).

Honey, M. (2008). Ecotourism and sustainable development: who owns paradise?. Island Press, Washington, DC.

Idowu, B., Atufe, F., Osuagwu, N., Bello, O., Echenin, S., Ogunmila, T. \& Okeke, C. (2014). How Ebola is taking toll on Nigeria Economy, http://leadership.ng/business/381861/ebola-takingtoll-nigerias-economy, accessed on 04.02 .2015 .

Ilies, D.C., Buhas, R., Ilies, M., Ilies, A., Gaceu, O., Pop, A.C., Marcu, F., Buhas, S.D., Gozner, M., \& Baias, S. (2018). Sport Activities and Leisure in Nature 2000 Protected Area - Red Valley, Romania. Journal of Environmental Protection and Ecology, 19, No 1, 367-372.

Ilieș, D. C., Oneț, A., Marcu, F.M., Gaceu, O.R., Timar, A., Baias, S., Ilieș, A., Herman, G.V. Costea, M., Țepelea, M., Josan, I. \& Wendt, J. (2018). Investigations regarding the air quality in the historic wooden church in Oradea city, Romania, in Environmental Engineering and Management Journal, Vol.17, no11, pp.2731-2739, http://www.eemj.icpm.tuiasi.ro/pdfs/accepted/204_294_Ilie\%C8\%99_17.pdf.

Ilieș, D.C., Oneț, A., Herman, G.V., Indrie, L., Ilieș, A., Burtă L., Gaceu, O., Marcu, F., Baias, S., Caciora, T., Marcu, A.P., Pavel, O.I., Costea, M., Ilieș, M., Wendt, J. \& Mihincău D. (2019), Exploring the indoor environment of heritage buildings and its role in the conservation of valuable objects, Environmental Engineering and Management Journal, December Vol. 18, No. 12, 2579-2586.

Indrie L., Ilieș, D. C., Oneț, A., Wendt, J. Ilieș, M., Timar, A., Ilieș, A., Baias, S. \& Herman, G.V. (2019). Indoor air quality of museums and conservation of textiles art works. Case study: Salacea Museum House, Romania, Industria textile, Vol. 70 No 1, pp 88-93.

Kanlayanasukho, V. (2014). An analysis of the tourism industry's management responses to political crises in Thailand. in Ritchie, B.W. \& Campiranon, K. (eds). Tourism crisis and disaster management in the AsiaPacific, CABI Publishing, Wallingford.

Kimbu, A.N. \& Tichaawa, T.M. (2018). Sustainable development goals and socio-economic development through tourism in central Africa: Myth or reality? GeoJournal of Tourism and Geosites, 23(3), 780-796.

Kiper, T. (2013). Role of ecotourism in sustainable development. Advances in Landscape Architecture, www.intechopen.com/books/advances-in-landscape-architecture/role-of-ecotourism-insustainabledevelopment/, accessed 20.08.2019.

Korstanje, M.E. (2011). The fear of traveling: a new perspective for tourism and hospitality. Anatolia, 22(2), $222-233$. 
Kuto, B.K. \& Groves, J.L. (2004). The effect of terrorism: evaluating Kenya's tourism crisis, e-Review of Tourism Research, 2(4), 88-94.

Lincu, A., Ilieș, M., Ilieș, D.C., Herman, G.V., Baias, S., Gozner, M., Costea, M., \& Mihincău, D. (2018). Conservating the traditional cellars of Salacea, Bihor County, Romania. GeoJournal of Tourism and Geosites, 23(3), 748-758, https://doi.org/10.30892/gtg.23311-325.

Manful, E. \& Eshun, G. (2015). Ethical Ethos in Cross-National Social Research: Ghanaian researchers' reflections. International Journal of Research in Social Sciences, 5(1), 238 - 251.

Mensah, I. \& Adofo, E. (2013). Community participation in ecotourism: the case of Bobiri Forest Reserve and Butterfly Sanctuary in Ashanti Region of Ghana. American Journal of Tourism Management, 2, 34-42.

Mkono, M. (2013). African and Western tourists: object authenticity quest?. Annals of Tourism Research, 41, 195-214.

Moreira, P. (2007). Aftermath of crises and disasters: notes for an impact assessment approach. In Laws, E., Prideaux, B. \& Chon, K. (eds). Crisis management in tourism, CABI Publishing, Wallingford.

Pennington-Gray, L. \& Schroeder, A. (2013). International tourist's perceptions of safety and security: the role of social media. Matkailututkimus, 9(1), 7-20.

Qu, H., Kim, L.H. \& Im, H.H. (2011). A model of destination branding: integrating the concepts of the branding and destination image. Tourism Management, 32, 465-476.

Ramón-Hidalgo, A.-E., Kozak, R.A., Harshaw, H.W. \& Tindall, D.B. (2018). Differential effects of cognitive and structural social capital on empowerment in two community ecotourism projects in Ghana. Society and Natural Resources, 31(1), 57-73.

Regmi, K.D. \& Walter, P. (2017). Modernisation theory, ecotourism policy, and sustainable development for poor countries of the global South: perspectives from Nepal. International Journal of Sustainable Development and World Ecology. 24(1), 1-14.

Romero-Brito, T.P., Buckley, R.C. \& Byrne, J. (2016). NGO partnerships in using ecotourism for conservation: systematic review and meta-analysis. PLOS ONE, 11(11).

Rusko, M. \& Prochazkova, D. (2011). Solution to the problems of the sustainable development management. Research papers, Faculty of Materials Science and Technology, Slovak University of Technology.

Scheyvens, R. and Momsen, JH. (2008). Tourism and Poverty Reduction: Issues for Small Island States, Tourism Geographies, 10(1):22-4.

Tarlow, P.E. (2011). Tourism risk management in an age of terrorism. Economía Autónoma, 4(7), 18-30.

Tosun, C. (2000). Limits to community participation in the tourism development process in developing countries. Tourism Management, 21(6), 613-633.

Ural, M. (2015). Importance of risk management for the sustainability of tourism. Journal of Social Sciences Institute, 18(33), 163-178.

Rogerson, C.M. (2015). Tourism and regional development: The Case of South Africa's distressed areas. Development Southern Africa, 32 (2), 277-291.

Weaver, D.B. \& Lawton, L.J. (2007). Twenty years on: the state of contemporary ecotourism research. Tourism Management, 28(5), 1168-1179.

Yang, C.L. \& Nair, V. (2014). Risk perception study in tourism: are we really measuring perceived risk?. Procedia - Social and Behavioral Sciences, 144, 322-327.

*** COMCEC Coordination Office. (2017). Risk and crisis management in tourism sector: recovery from crisis in the OIC member countries report. The Office, Ankara.

*** Ghana Statistical Service. (2010). Population and housing census: Central Region, Analysis of District Data and Implications for Planning. Accra: Ghana.

*** National Planning Commission. (2015). Nepal earthquake 2015: post disaster needs assessment. NPC, Kathmandu.

*** National Disaster Management Organisation. (2015). Disaster at Bunso, retrieved from https://mobile.ghanaweb.com/GhanaHomepage/regional/Bunso-Canopy-Walkway-Incident-wascaused by-overloading/ Accessed/20/08/18.

*** Pacific Area Travel Association (PATA). (2003). Crisis. It won't happen to us!. PATA, Bangkok.

*** Pacific Area Travel Association (PATA). (2011). Bounce back - tourism risk, crisis and recovery management guide, PATA, Bangkok.

*** Wildlife Division. (2000). Wildlife Division Policy for Collaborative Community Based Wildlife Management. September 200o. Accra: Wildlife Division.

*** World Bank .(2006). Not if But When: adapting to natural hazards in the Pacific Islands Region. The World Bank, Sydney

*** World Bank. (2018). Improving vocational training and skills development delivery systems for the tourism sector in Ghana. Unpublished, Accra.

*** World Travel and Tourism Council. (2019). Travel and tourism economic impact 2017, South Africa. WTTC, London.

Submitted:

26.10.2019
Revised:

28.02.2020
Accepted and published online

04.02.2020 